\title{
Negative Prognostic Factors in Severe Burns - Implication for Clinical Outcome
}

\author{
Mihaela-Cristina Andrei ${ }^{1}$, Andreea Grosu-Bularda', Oana Vermesan', Serban Arghir Popescu ${ }^{1,2}$,
}

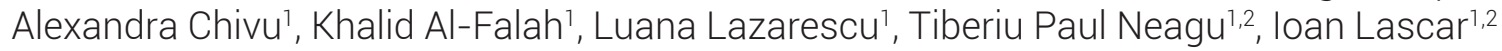

\begin{abstract}
Introduction: Severe burn injuries still are a major challenge for the entire healthcare system. Multiple predictive factors may influence the prognosis of burn patients and a careful management of those parameters will decrease the morbidity and mortality and will determine an improvement in patient's final functional outcome. Material and Methods: We present a two years study on the burn patients hospitalized in our institution. A total of 355 burned patients were hospitalized during this period, 210 (59\%) of them being addmited in Critical Care Burn Unit. A detailed analysis was performed on those 210 critical patients in order to determine the parameters that aggravate the prognosis of burn injuries. A large data panel was taken into consideration regarding burn severity, mechanism of injury, patient characteristics, associated illnesses, promptitude in hospitalizing the patient in our burn center; ABSI score was used to evaluate the mortality risk, burn injury-associated complications were noted and analyzed. Results and discussion: We highlighted a series of parameters regarding therapeutic management that influence the outcome of the patient after severe burn injury: an adequate hydro-electrolytic resuscitation in the acute phase, further support of vital functions, early excision and grafting of deep burn injuries, comorbidities treatment and adherence to rehabilitation and follow-up program. ABSI Score is an important tool in the assessment of mortality in burn patients. Multiple complications were encountered in our patients: infections, pulmonary, cardiac, renal, thrombo-embolic, hematologic, digestive and neurologic disorders. Conclusion: A detailed analysis of the physiopathology of burn injuries and their complications is essential for providing an adequate prompt treatment for decreasing morbidity and mortality. Mortality still represents the primary outcome evaluation for burn care, therefore scoring systems aim to use the most predictive patient and injury-related parameters to appreciate an expected mortality for a given patient. Early excision of the devitalized tissue and subsequent grafting reduce the local and systemic effects of the mediators released from the burned tissue with cessation of the progressive inflammatory chain. Early recognition and treatment of burns complications, especially severe infections represent an important prevention strategy, improving survival after these severe injuries.
\end{abstract}

Keywords: severe burns, negative prognosis factors, ABSI score, complications, mortality.

\section{Rezumat}

Introducere: Arsurile severe reprezintă în continuare o provocare majoră pentru întregul sistem de sănătate. O serie de factori pot influența prognosticul pacienților cu arsuri grave și în consecință identificarea și sanctionarea corectă a acestor parametri ar putea reduce morbiditatea și mortalitatea și determina o îmbunătățire a rezultatelor funcționale finale ale pacientului. Material și metodă: Prezentăm un studiu desfășurat pe o perioadă de doi ani a pacienților cu arsuri severe spitalizați în

${ }^{1}$ Clinic of Plastic Surgery, Aesthetic and Reconstructive Microsurgery, Emergency Clinical Hospital Bucharest, Romania ${ }_{2}$ "Carol Davila" University of Medicine and Pharmacy, Bucharest, Romania

\section{Corresponding author.}

Andreea Grosu-Bularda

Emergency Clinical Hospital, Calea Floreasca no. 8, Bucharest,

Romania.

E-mail: andreeabularda@gmail.com 
unitatea noastră. Un număr de 355 de pacienți arși au fost internați în această perioadă, 210 (59\%) dintre aceștia fiind admiși în Unitatea de Îngrijire a Arșilor Grav. O analiză detaliată a fost efectuată pe cei 210 pacienți critici, pentru a determina parametrii care agravează prognosticul leziunilor postcombustionale. Un număr mare de date a fost luat în considerare în ceea ce privește gravitatea arsurilor, mecanismul de acțiune, caracteristicile pacientului, bolile asociate, promptitudinea internării pacientului în unitatea noastră; scorul ABSI a fost utilizat pentru a evalua riscul de mortalitate, au fost notate și analizate complicațiile apărute. Rezultate și discuții: Au fost subliniați o serie de parametri ce țin de managementul terapeutic, care influențează rezultatul pacientului cu arsuri grave: resuscitarea hidro-electrolitică adecvată în faza acută, susținerea funcțiilor vitale, excizia precoce și grefarea arsurilor profunde, tratamentul comorbidităților și aderarea la programul de recuperare. Scorul ABSI este un instrument important în evaluarea mortalității la pacienții cu arsură. S-au observat complicații multiple la pacienții noștri: infecții, afecțiuni pulmonare, cardiace, renale, tromboembolice, hematologice, digestive și neurologice. Concluzii: $\mathrm{O}$ analiză detaliată a fiziopatologiei leziunilor de arsură și a complicațiilor acestora este esențială pentru asigurarea unui tratament adecvat, instituit prompt, în vederea scăderii morbidității și a mortalității. Mortalitatea reprezintă în continuare principalul criteriu de evaluare a rezultatelor pentru îngrijirea arsurilor, prin urmare scorurile prognostice includ parametrii cei mai predictibili ce caracterizează pacientul și leziunea, pentru a aprecia cât mai exact mortalitatea așteptată pentru un anumit pacient. Excizia precoce a țesuturilor devitalizate și grefarea defectelor tegumentare reduc efectele locale și sistemice ale mediatorilor eliberați din leziunea de arsură, cu întreruperea lanțului inflamator. Recunoașterea precoce și tratamentul complicațiilor arsurilor, în special infecțiile severe, reprezintă o strategie importantă de prevenție, îmbunătățind supraviețuirea în cazul acestei patologii extrem de grave.

Cuvinte cheie: arsuri severe, factori pentru un prognostic negativ, scorul ABSI, complicații, mortalitate.

\section{INTRODUCTION}

Burn injuries are a major public health problem all over the world and despite significant improvements in critical care and surgical treatment, major burns are associated with high morbidity and mortality and poor recovery outcome. Patients with severe burns need immediate intervention and rapid initiation of specialized treatment in a dedicated critical care burn unit in order to minimize morbidity and mortality. The complex nature of burn injuries requires an integrative approach, by a multidisciplinary team in order to obtain an optimal care.

Multiple factors may influence the prognosis of burn patient's therefore an appropriate identification and a careful management of those parameters will decrease the morbidity and mortality and will determine an improvement in patient's final functional outcome.

We reviewed the literature and summarized a list of factors that should be taken into account in the evaluation of burns prognosis, presented in Table 1:
Several specific burn outcome prognostic scores were developed to predict mortality in burned patients, to enable comparative research and to facilitate decision-making in this field. The goal of scoring systems

\begin{tabular}{l}
\hline \multicolumn{2}{l}{ Table 1. Factors that influence burn severity ${ }^{1-9}$} \\
\begin{tabular}{|l|l|}
\hline FACTOR & SEVERITY \\
\hline TBSA & Extensive burns \\
\hline Depth of burn & II B and III degree burns \\
\hline Age & Extreme ages \\
\hline Gender & Female \\
\hline Body parts involved & Functional areas \\
\hline Inhalation injury & Airway burns \\
\hline Mechanism of injury & $\begin{array}{l}\text { Explosion->inhalation injury } \\
\text { Electrocutions } \\
\text { Chemical Burns }\end{array}$ \\
\hline History of associated diseases & $\begin{array}{l}\text { Cardiac, pulmonary, renal, hepa- } \\
\text { tic, diabetes, autoimmune etc. }\end{array}$ \\
\hline Concomitant injuries & $\begin{array}{l}\text { Politrauma } \\
\text { Internal lesions }\end{array}$ \\
\hline Psycho-social factors & $\begin{array}{l}\text { Psychiatric pathology } \\
\text { Social cases }\end{array}$ \\
\hline
\end{tabular}
\end{tabular}


is an accurate evaluation of the severity of the trauma, estimation of the prognosis for the patient, allowing a stratification of patients that guide therapeutic strategies $^{6,8}$. A prognostic score that has proven useful over the years for mortality prediction is the Abbreviated Burn Severity Index (ABSI score), introduced by Tobiasen et al. in $1982^{6,10}$.

Therapeutic measurments correctly applied to burn patients are a major determinant of the final outcome. Severe burn treatment is very complex and it is mandatory to be adapted to the dynamic physiopathological changes observed after combustional lesions.

Three major phases are described in the evolution of burn injuries, each one with specific therapeutic management (Table 2):

It is very important to rapidly identify the complications, especially infections, and apply the specific therapeutic measures throughout the patient course during these phases. The current recommendations are to avoid the development of organ dysfunction and to ensure adequate support to elude conditions that favor its onset. Early excision of the burn eschar and wound grafting, rapid mobilization of the patient and prompt identification and treatment of any systemic disorder determine the achievement of this goal ${ }^{1}$.

\section{MATERIAL AND METHOD}

We investigated a total number of 355 burned patients hospitalized in Bucharest Clinical Emergency Hospital for 2 years, between 01.05. 2016-01.05.2018, 210 (59\%) of them being addmited in Critical Care Burn Unit.

A detailed analysis was performed on those 210 critical patients in order to determine the parameters that aggravate the prognosis of burn injuries. A large panel of data was taken into consideration regarding burn severity, mechanism of injury, patient characteristics, associated illnesses, promptitude in hospitalizing the patient in the burn center; ABSI score was used to evaluate the mortality risk, burn injury-associated complications were noted and analyzed. A statistical study was performed in order to determine the correlation between ABSI burn prognostic score and the observed mortality.

ABSI Score was calculated after Tobiasen scheme as we can see in Table 3.

\section{RESULTS}

We evaluated the mortality of all admitted patients in our unit and we noticed a total mortality of $36.6 \%$, as seen in Graphic 1 with a mortality of $60.4 \%$ of patients admitted on Critical Care Burn Unit, as seen in Graphic 2.

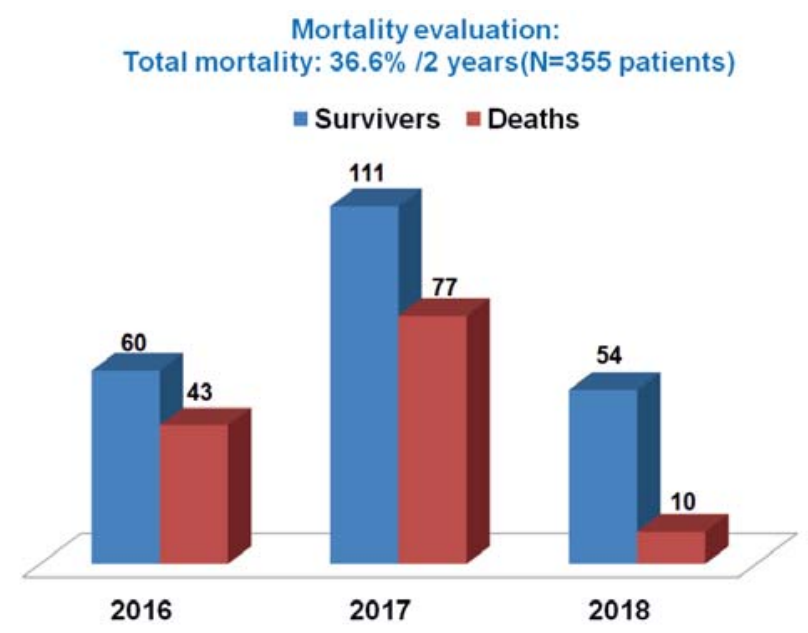

Graphic 1 . Mortality evaluation on total number of patients.

Table 2 . The phases of burn injury management ${ }^{11,12}$

\begin{tabular}{|l|l|l|}
\hline PHASE & \multicolumn{1}{|c|}{ DURATION } & \multicolumn{1}{|c|}{ GOALS } \\
\hline EMERGENT & $\begin{array}{l}\text { From the moment of injury until the com- } \\
\text { plete fluid resuscitation (the first 72 hours) }\end{array}$ & $\begin{array}{l}\text { Prevention of burn shock and management of fluid loss is } \\
\text { critical } \\
\text { Prevention of respiratory distress } \\
\text { Treatment of concomitant injuries } \\
\text { Wound assessment }\end{array}$ \\
\hline ACUTE & $\begin{array}{l}\text { From day 4 (hemodynamic stabile and } \\
\text { the beginning of diuresis) until the wound } \\
\text { closure }\end{array}$ & $\begin{array}{l}\text { Prevent infection } \\
\text { Provide metabolic support } \\
\text { Wound care and closure, } \\
\text { Respiratory therapy } \\
\text { Psychological and psychiatric therapy }\end{array}$ \\
\hline REHABILITATION & Final part, extends beyond hospitalization & $\begin{array}{l}\text { Reintegration into society } \\
\text { Essential to both physical and emotional healing. }\end{array}$ \\
\hline
\end{tabular}


Mortality in Critical Burn Unit Patients Total mortality: $60,4 \% / 2$ years ( $\mathrm{N}=210$ patients)

" Survivers $=$ Deaths

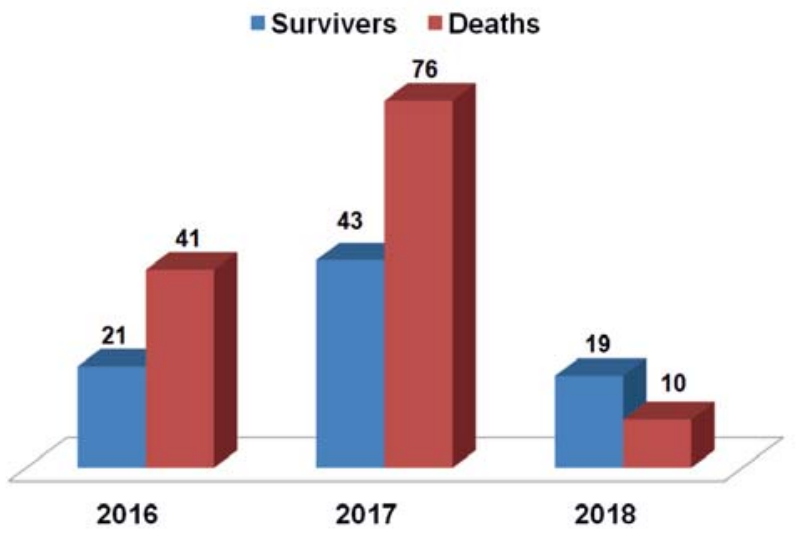

Graphic 2. Mortality evaluation in patients admitted on Critical Care Burn Unit.

We traced the moment of death in our patients and we noticed a total of 20 deaths in the first 72 hours, which is the emergent phase, as seen in Graphic 3.

Patient characteristics were evaluated in our study group. The distribution of home environment in pati-

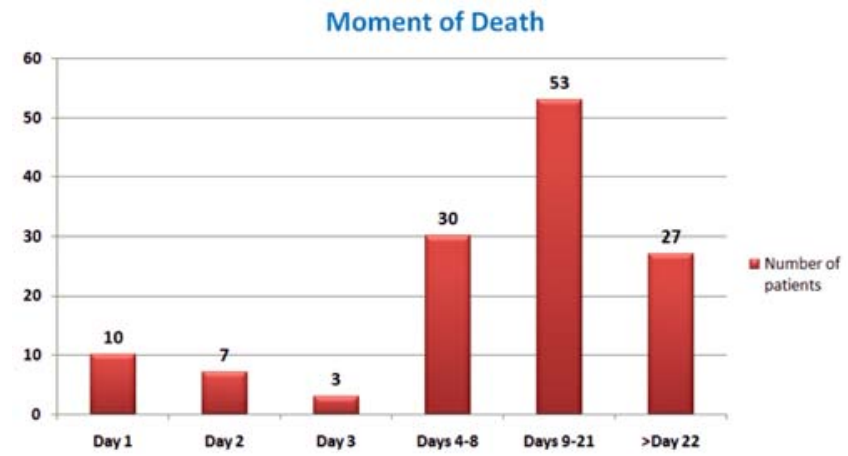

Graphic 3. Moment of death of patients admitted on Critical Care Burn Unit.

ents admitted in the Critical Care Burn Unit is 46.6\% living in urban areas and $53.3 \%$ living in rural areas. Gender distribution was $66 \%$ male patients and 34\% females.

In Graphic 4 we present the distribution of our critical patients' age groups and we can see a maximum number of patients in the group between 41 and 60

Table 3. The abbreviated burn severity index (ABSI score) ${ }^{10}$

\begin{tabular}{|c|c|c|}
\hline Variable & Characteristic of the patient & Score \\
\hline \multirow[t]{2}{*}{ Sex } & Male & 0 \\
\hline & Female & 1 \\
\hline \multirow[t]{5}{*}{ Age (years) } & $0-20$ & 1 \\
\hline & $21-40$ & 2 \\
\hline & $41-60$ & 3 \\
\hline & $61-80$ & 4 \\
\hline & $81-100$ & 5 \\
\hline Inhalation injury & & 1 \\
\hline Full thickness burn & & 1 \\
\hline \multirow[t]{10}{*}{ TBSA burned (\%) } & $1-10$ & 1 \\
\hline & \begin{tabular}{|l|}
$11-20$ \\
\end{tabular} & 2 \\
\hline & $21-30$ & 3 \\
\hline & $31-40$ & 4 \\
\hline & $41-50$ & 5 \\
\hline & $51-60$ & 6 \\
\hline & $61-70$ & 7 \\
\hline & $71-80$ & 8 \\
\hline & $81-90$ & 9 \\
\hline & $91-100$ & 10 \\
\hline Total burn score & Threat to life & Survival probability (\%) \\
\hline $2-3$ & Very low & $\geq 99$ \\
\hline $4-5$ & Moderate & 98 \\
\hline $6-7$ & Moderately severe & $80-90$ \\
\hline $8-9$ & Serious & $50-70$ \\
\hline $10-11$ & Severe & $20-40$ \\
\hline$\geq 12$ & Maximum & $<10$ \\
\hline
\end{tabular}




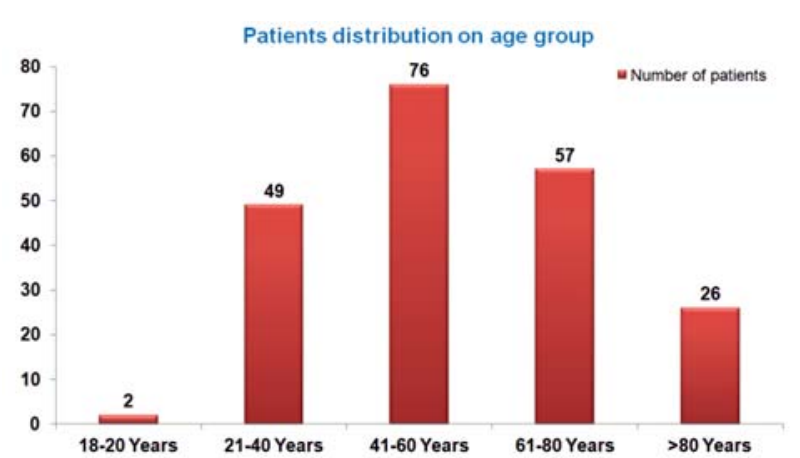

Graphic 4. Distribution on age of patients admitted on Critical Care Burn Unit.

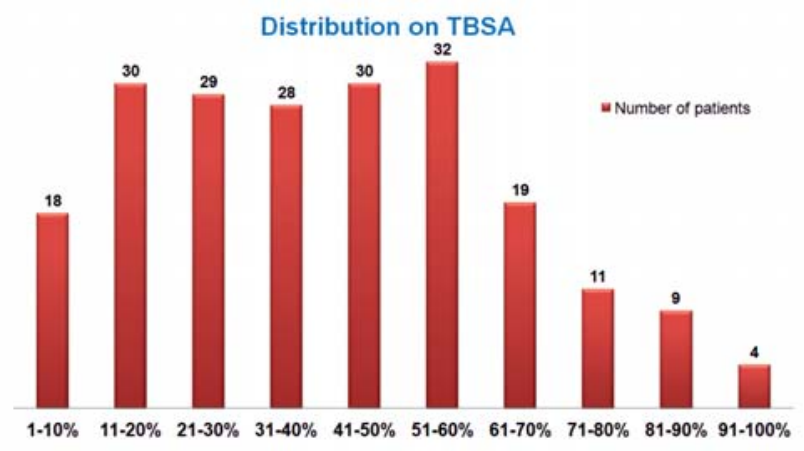

Graphic 5. Distribution on TBSA of patients admitted on Critical Care Burn Unit.

years old (76 patients) and a large elderly group, after 61 years old (81 patients).

Regarding the extent of burn lesions in our group, Graphic 5 is showing $63.3 \%$ of patients with $\geq 30 \%$ burned TBSA.

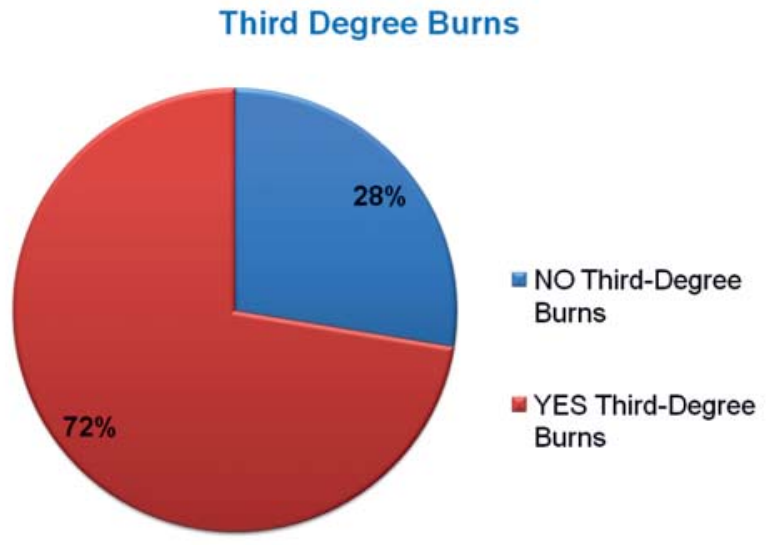

Graphic 6. Distribution of third degree burns in patients admitted on Critical Care Burn Unit.
Table 4. Concomitant injuries

\begin{tabular}{|l|l|}
\hline \multicolumn{2}{|c|}{ Concomitant injuries } \\
\hline Costal fractures & Aspiration Pneumonia \\
Limb fractures & Cranio-crerebral trauma \\
Pneumothorax & Intra-abdominal hemorrhage requiring sple- \\
& nectomy \\
\hline
\end{tabular}

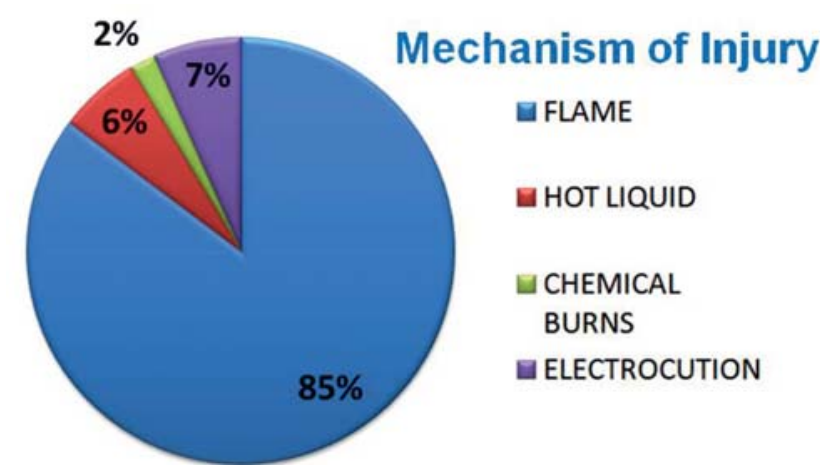

Graphic 7. Distribution of mechanism of injury in patients admitted on Critical Care Burn Unit.

The burn depth was analyzed for its influence for burn severity and as we can see in Graphic 6, there were $72 \%$ of patients having a third degree burn.

Taking into account the mechanism of injury as one of the negative prognostic factors in our study we encountered a number of 73 explosions (34\% of patients), $7 \%$ electrocutions and $2 \%$ chemical burns, as seen in Graphic 7. In 23 patients there were work-related burns (11\% of patients).

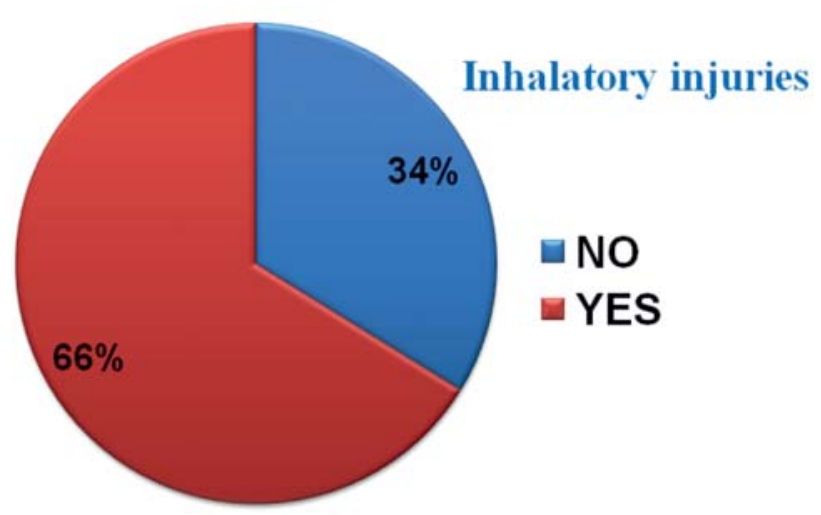

Graphic 8. Inhalation injury of patients admitted on Critical Care Burn Unit. 
Graphic 9. Hours of mechanical ventilation per patient.

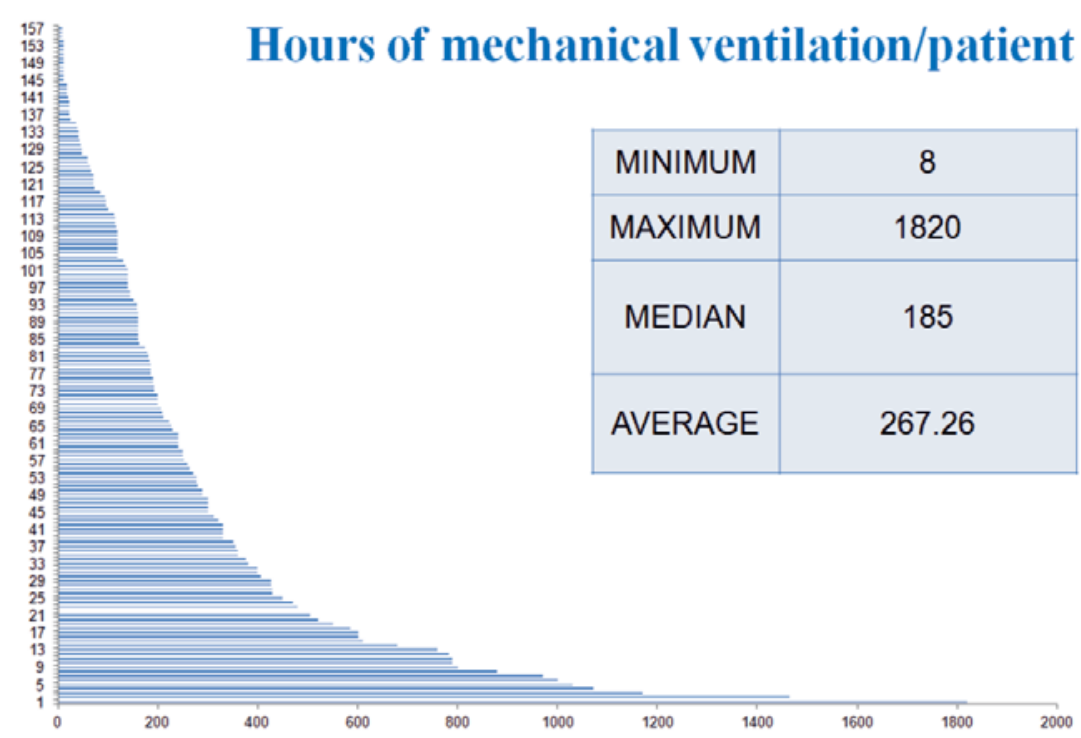

We followed the presence of inhalation injury in our patients and determined 66\% affected patients as we can see in Graphic 8.

We noticed that 156 patients from 210 (74.3\%) required intubation and mechanical ventilation, with an average of 267 hours of mechanical ventilation/patient with a median of 185 hours/patient (Graphic 9). A total of 22 tracheostomies were performed by our ENT surgeons.

The association of concomitant injuries aggravates the prognosis of the burn patients and we can notice in our study the presence of costal and limb fractures, pneumothorax, aspiration pneumonia, cranio-cerebral trauma and intra-abdominal hemorrhage, as seen in Table 4.

ABSI score was calculated in our study for asses its role in mortality prediction. In the Graphic 10, the

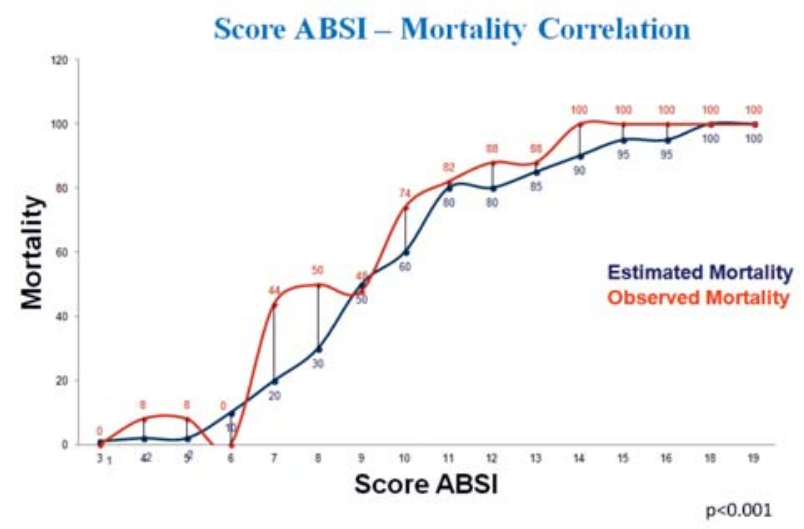

Graphic 10. Correlation between the ABSI score and mortality. correlation between the ABSI score and mortality is illustrated in the study group with a very high correlation $(r=0.9310)$ and with high statistical significance $(p<0.001$, confidence of $99.9 \%)$ between the ABSI score and the observed mortality; a very high correlation $(r=0.9539)$ with statistical significance $(\mathrm{p}<0.0075$, confidence of 99\%) between the ABSI score and the estimated mortality is also seen.

We looked at the modality of hospital admission and we observed a large number of transferred patients from other centers-60\%, 40\% being direct admissions (Graphic 11). There were 126 patients transferred from other centers: $82(65 \%)$ of patients were transferred during the first day of the injury and 44 (35\%) of patients after 24 hours.

During hospitalization in our Critical Care Burn Unit, 133 patients (63.3\%) developed systemic com-

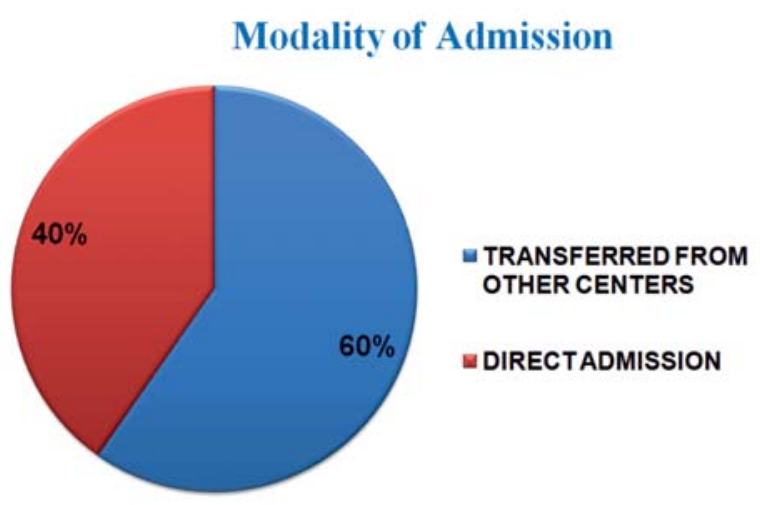

Graphic 11. Transfers from other centers. 


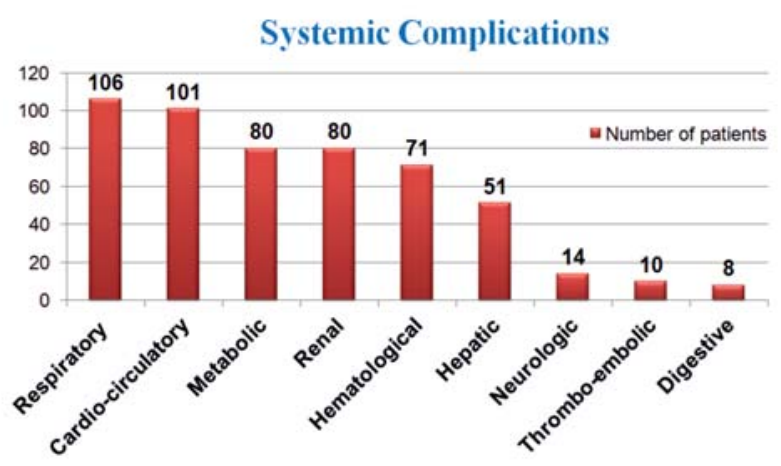

Graphic 12. Systemic complications.

DAY 1

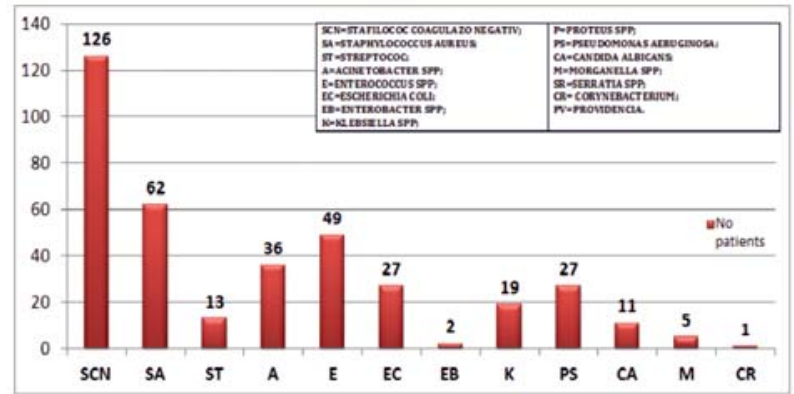

Graphic 13. Germs distribution in first day of admission in our unit.

plications (Graphic 12) and 10 of those patients required renal substitution therapy. Other complications as ophthalmological, psychiatric and dermatological were also seen in a smaller amount of cases.

Infectious complications were assessed separately in our study. In Graphics 13-16 we notice the fluctuation of microbial distribution in our patients at admission, day 7, day 14 and day 21, as we wanted to note sequentially the microbial distribution map in our burned patients, in order to evaluate and determine the infectious pattern during the evolution phases of burn injury.

The screening on admission noticed the expected saprophyte flora (126 cases of coagulase negative Staphylococcus, 62 cases of Staphylococcus aureus and 13 cases of different types of Streptococcus), but also 36 cases of Acinetobacter, 49 cases of Enterococcus, 27 cases of Escherichia coli, 27 cases of Pseudomonas aeruginosa, that in many cases are associated with antibiotic resistance (Graphic 13).

The screening on day 7 noticed a decrease of the expected saprophyte flora (29 cases of coagulase negative Staphylococcus, 9 cases of Staphylococcus aureus), but also 52 cases of Acinetobacter, 33 cases of Klebsiella, 6

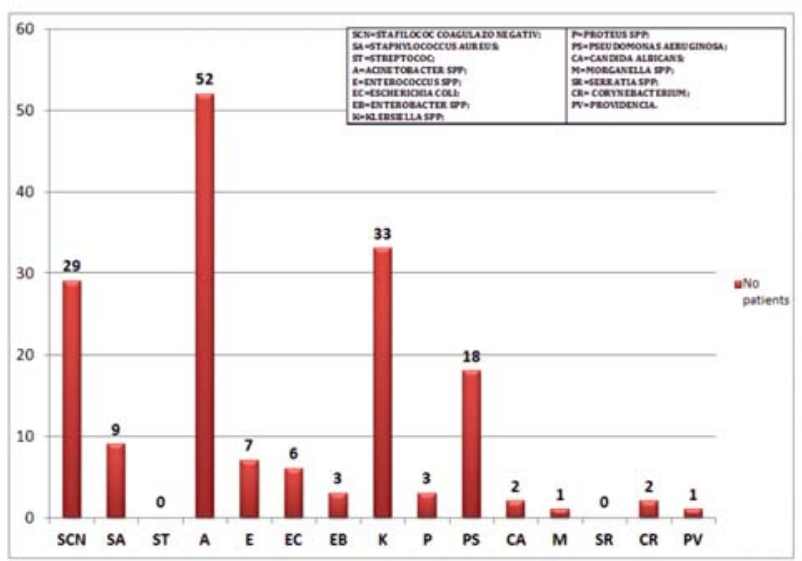

Graphic 14. Germs distribution in day 7 of hospitalization in our unit.

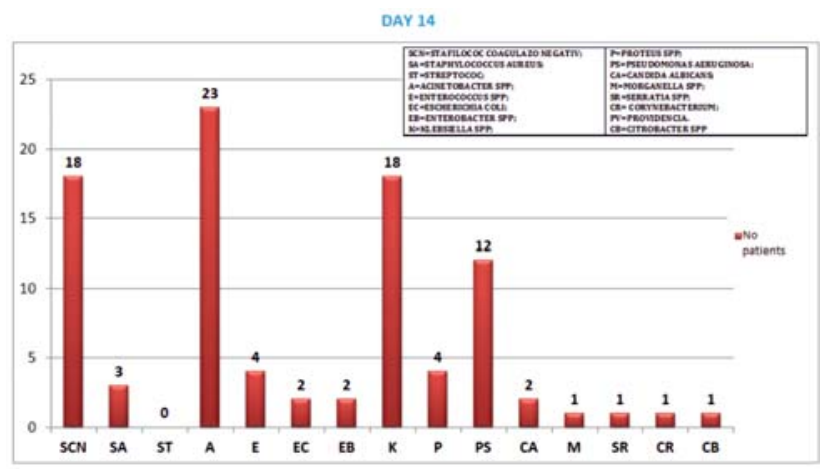

Graphic 15. Germs distribution in day 14 of hospitalization in our unit.

cases of Escherichia coli, 18 cases of Pseudomonas aeruginosa (Graphic 14).

The screening on day 14 , the study group is smaller due to the occurred deaths, but we noticed 18 cases of coagulase negative Staphylococcus, 23 cases of Acinetobacter, 18 cases of Klebsiella, 2 cases of Escherichia coli, 18 cases of Pseudomonas aeruginosa (Graphic 15).

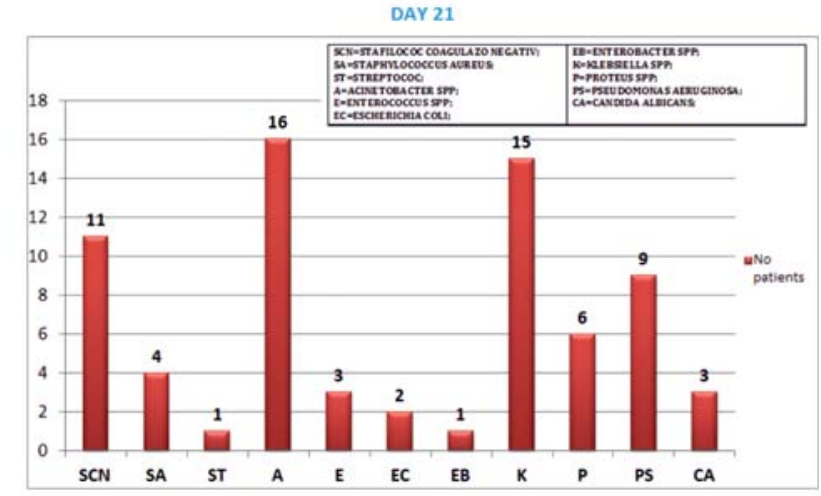

Graphic 16. Germs distribution in day 21 of hospitalization in our unit. 
The screening on day 21 revealed 11 cases of coagulase negative Staphylococcus, 16 cases of Acinetobacter, 15 cases of Klebsiella, 2 cases of Escherichia coli, 9 cases of Pseudomonas aeruginosa (Graphic 16).

\section{DISCUSSION}

Major burns are a serious problem for our national health system as for other developing countries and even for states with a high standard of care. Each year, in United States 500000 patients visit the emergency departments for burn injuries, from these around 40000 patients present severe burn injuries requiring hospitalization with 4000 deaths per year. Severe burn injuries lead to severe systemic alterations being associated with high risk of morbidity and mortality ${ }^{1-3}$.

Trough this paper we tried to identify the large panel of factors that may influence the prognostic of patients with severe burn injuries with the aim to improve and standardize our practice in order to reduce the complications, decrease the morbidity and mortality rates for better final outcome of those problematic patients. Patient-related and injury-related characteristics were analyzed and also particularities encountered in our center were noted.

Demographical characteristics (the residence environment, gender, age) of the patient are taken into consideration in relationship with burn injury prognosis.

We noticed a slight predominance of rural-provenance patients in the case of hospitalizations in our Critical Care Burn Unit.

In France, Vidal-Trecan et al. identified higher severity of burns from rural areas: there are usually produced outdoor, due to flames, explosions or open fire; in these report rural burns were more extensive, involving a larger TBSA, deeper and determined more deaths than urban burns ${ }^{13}$. In a Turkish study performed by Tarim MA., burns produced in rural areas were also deeper, larger, and causing more deaths than those from urban areas, probably due to the particularities of the rural population, including the delay of transportation to the burn units ${ }^{14}$. Mian et al. published a study on urbanrural dichotomy of burn patients from United States (data from Georgia and South Carolina) and highlight the socioeconomic disparities between the urban and rural population, with young urban population groups that live in poor socioeconomic status communities being at the higher risk. For the rural areas the access to medical facilities is more difficult and also the burn unit referral is delayed ${ }^{15}$.
This rural-urban difference is also valid in our geographic region, with patients coming from rural areas attending later the territorial medical service and consequently presenting a delay in the admission to the burn unit.

The gender distribution in our group was approximately $2: 1$, favoring for male patients. As regarding age group distribution, $36.2 \%$ of our patients were between 41-60 years. We noticed a large group of elderly patients over 61 years (38.6\%).

In a large study published by Li et al. on 6325 pediatric and adult burn patients, the gender analysis show a male patients predominance(male-to-female ratio was $2: 1)$; in the adult study group the main affected age decade being $41-60$ years $(26.2 \%)^{16}$.

Older patients are the most vulnerable to the morbidity and mortality associated with burn injuries, therefore preventive strategies should be developed and promoted in elderly population group ${ }^{17}$. Lionelli et al. attested age as a significant variable for mortality prediction, in their study (independent of TBSA and inhalation injury-holding constant those two parameters), they found that the mortality risk was multiplied by a factor of 1.1 for each additional year in patient's age $^{18}$.

A study conducted by Lundgren et al. demonstrated that the age of patients, independent of existing comorbidities, along with inhalation injury and TBSA involved are the most significant parameters that determine the mortality risk during hospitalization after burn injury ${ }^{19}$.

We had a large proportion of extensive burns: $63.3 \%$ over $30 \%$ TBSA, $50 \%$ of our patients having more than $40 \%$ TBSA, suggesting a poor prognostic.

Morbidity and mortality risk depends on TBSA, increasing in a linear manner: the more extensive is the burn, the higher is the risk. Jeschke et al. established a critical threshold for morbidity and mortality after burn injuries at 40\% TBSA burned for adult patients and $60 \%$ TBSA burned in pediatric patients, showing that patients with burns at or exceeding these cutoff values are at high risk for severe complications and death, even if they are treated in highly specialized burn centers. The same study has also taken into account the age of the patients and set a lower survival cutoff at around $30 \%$ TBSA for elderly patients ${ }^{20}$.

The burn depth, with presence of third degree burn is part of the factors that influence burn severity and in our group we encountered a large proportion of patients (72\%) with full thickness burns. These cases 
require surgical treatment in order to improve their prognosis.

The standard of care is represented by the early excision and grafting of the full thickness burn wounds: early excision decrease infections risk, length of hospital stay and mortality (mortality is decrease when burns are not associated with inhalation injury); burn eschar excision is associated with increased need of blood transfusion ${ }^{21,22}$.

If possible, the excised burn wound is covered with a split-thickness autograft, which can be meshed with different expansion rate to increase its surface. Patients presenting extensive deep burns don't have sufficient available donor sites for autografting and they need temporary or permanent coverage with skin substitutes: temporary coverage with human allografts, xenografts, synthetic or biosynthetic products or definitive coverage with compounds like cultured epidermal autografts, dermal substitutes(Integra, Alloderm, Matriderm) or bi-layered products (Apligraf) ${ }^{21,23,24}$.

Regarding burns etiology, in our group 85\% were flame injuries and in $34 \%$ of cases explosion was the cause. This distribution of predominant mechanism usually associates with severe burns of functional areashead and upper extremities and also with airway burns, a major negative prognostic factor. Two-thirds of our patients in the Critical Care Burn Unit presented inhalation injuries and three quarters of the 210 critical patients required intubation and mechanical ventilation. Airway burns are evaluated in our center using the fiber-optic bronchoscope.

Inhalation injuries in burn patients are still associated with an important morbidity and mortality rate ${ }^{25}$. The inhalation injury is noted to be an independent factor for mortality prediction in burn patients and worsens survival even among patients of same age and burn size ${ }^{26}$. The inflammatory response in the case of inhalation injuries requires increased fluid resuscitation volumes compared to burn patients alone, determines progressive pulmonary dysfunction, requires more ventilation days, increases the risk of pneumonia, and acute respiratory distress syndrome (ARDS) ${ }^{25,27}$. The retrospective study made by Swanson et al. ( $\mathrm{n}=5975$ patients) during a 12-year period showed that inhalation injuries in burn patients are the second most common cause of death in the first week (16\%) after the burn injury, the first cause being the burn shock $(62 \%)^{28}$.

The clinical diagnosis of inhalation injuries is subjective: includes the existence of facial burns, singed nasal vibrissae, a history of exposure to smoke in a closed space, the presence of carbonaceous sputum, changes in voice, stridor, wheezing ${ }^{25,29,30}$.

Nowadays, the standard for diagnosis of inhalation injury in most major burn centers is fiber-optic bronchoscopy. The limitation of this investigation is the impossibility to evaluate the distal airways ${ }^{31}$. There has been found a correlation between the severity of inhalation injury assessed with fiber-optic bronchoscopy and mortality ${ }^{32}$. An analysis made by Ryan et al., based on a retrospective review by Hassan et al. of 105 patients admitted with inhalation injury, has noted that the most reliable indicator of the inhalation injury is the $\mathrm{PaO}_{2} / \mathrm{FiO}_{2}$ ratio 32,33 .

There is no ideal strategy for the patients with inhalation injuries and the management consists of supportive care ${ }^{34}$.

It has been reported the benefit of noninvasive ventilation, but the best moment to use it in the burn injured patients is unclear ${ }^{35,36}$.

Studies have shown that tracheostomy is safe in burn patients, but there is no consensus when it is the best time to do it. Patients with major burns and with severe inhalation injury are those who can benefit from an early tracheostomy, because they need numerous surgical procedures and longtime ventilation ${ }^{37}$. Tracheostomy eases ventilator weaning by reducing dead space, airway resistance, work of breathing and the need for sedation ${ }^{38}$. With tracheotomy there is a shorter and a more direct airway access, the cough efforts and suctioning are likely to be more effective, patient comfort is improved, with earlier ability to speak. Overall tracheostomy seems to associate with lower risk of ventilator-associated pneumonia, lower mortality and shorter hospitalization and staying in intensive care unit in comparison with orotracheal intubation ${ }^{39}$.

An interesting study from United States was published by Kagan et.al.based on analysis of patients included in DRG (diagnosis related group) 504 Classification- burned patients with extensive injuries requiring skin grafts along with $\mathrm{f}$ patients with non-extensive third degree burns with skin grafts who need $>96$ hours (4 days) of mechanical ventilation: patients from this category who required $\geq 96$ hours of mechanical ventilation had around 10 times more the number of ventilator and intensive care unit hospitalization days in comparison with patients with extensive burns but with $<4$ days mechanical ventilation. These patients had also doubled length of hospitalization and cost than patients with $<96$ hours of mechanical ventilati$\mathrm{on}^{40}$. 
As we see, a prolonged period of mechanical ventilation transposes in a poor prognosis for the patient and high consumption of material resources, therefore this indicator (number of hours of mechanical ventilation) has to be analyzed more carefully in order to early diagnose and treat specific complications for improve patient outcome and also to develop an economic strategy for an adequate financial resource distribution to burn centers. This situation applies also in our case, due to long termed required mechanical ventilation in our patients (an average of 11.12 days of mechanical ventilation in our critical patients).

In a study published by Forster on 2813 patients with the aim to analyze the predictive value of ABSI score, it was seen that each of the variables of ABSI score is a significant predictor of mortality. Also they compared the estimated mortality of the patients using the ABSI score with the calculated mortality in the analyzed group and they validated the accuracy of the ABSI score in predicting burn patient's mortality, attesting this scientific value of the ABSI since more than 35 years from its introduction by Tobiasen et al. ${ }^{10,41}$.

We noticed similar results in our study: according to statistical significant data, ABSI score is a very important tool for prediction of mortality in our patients. We had high mortality levels, but those data were expected when we analyzed the prognostic scores, due to severity of each parameter encountered in our group of patients.

A particular situation encountered in our burn unit was a high proportion of patients transferred from other centers around the country, often for long distances reaching $600 \mathrm{~km}$, requiring different transport modalities (air transport by plane or helicopter and ambulance). Many of those patients were transferred after the first day from the moment of burn occurrence and we noticed the risk associated with these situations: inappropriate initial resuscitation, transport-related risk and an increased chance of infectious complications (in regional hospitals it is difficult to assess the appropriate isolation conditions that are mandatory for the burn patients). The ideal situation is the admission of the severely burned patient in a burn unit in the first 8 hour from injury occurrence.

It is essential for the burn patient to begin the liquid resuscitation right away and according to the Parkland formula: $4 \mathrm{ml}$ crystalloid solution $\mathrm{x} \mathrm{kg} x$ total burn area $=\mathrm{ml}$ for the first 24 hours, of which half will be given within the first 8 hours of injury (not from the moment when the patient is hospitalized), and the rest within the next 16 hours. The most adequate indicator for a good liquid resuscitation is the evaluation of diuresis: $0.5 \mathrm{ml} / \mathrm{kgc} / \mathrm{h}$. During the acute phase it is important to also evaluate the color of the urine (dark urine is a sign of myoglobinuria that may appear in massive burns or electrical burns)-if the color is dark, it is a high suspicion of kidney failure, requiring aggressive and prompt treatment ${ }^{1}$. This first phase, described as the ebb phase lasts the 48-72 hours of thermal injury with patients presenting oxygen consumption, decreased cardiac output and metabolic rate and are both glucose intolerant and hyperglycemic ${ }^{42}$. The primary goal after the acute phase is to restore and preserve tissue perfusion and prevent ischemia produced by post-combustion shock with hypovolemic and cellular disorders ${ }^{43}$.

After the acute, resuscitative phase, starts the flow or hypermetabolic phase. Severe burns determine a response that involves almost all biological systems. Systemic inflammation, hypermetabolic status with muscle wasting and resistance to insulin are hallmarks of the physio pathological response to major burns, which determine metabolic changes persisting for several years following burn injury ${ }^{43}$. During these phase multiple disorders may appear at different levels: cardiovascular, renal, pulmonary, neurological, gastrointestinal, hepatic, metabolic and immunologic ${ }^{43}$.

A large proportion of our patients developed systemic complications, more frequently affecting respiratory and cardio-circulatory systems, followed by metabolic, renal and hematological complications. Those situations require a specific supportive therapeutic management involving a multidisciplinary care-giving team, but in very difficult cases a poor outcome was encountered, despite intensive supportive therapy, patients developing multisystem organ failure with consecutive death for many of them.

Infections are the most sever and the most frequent complication and requires adequate diagnosis and treatment. We perform microbiological screening: testing at admission and once a week or in case of clinical signs from all potential sites. The antibiotherapy is administered according to antibiograms, but if needed, when clinical and paraclinical signs are suggestive for infection, the antibiotherapy is started empirical, with broad spectrum and immediately after the antibiogram is available, targeted antibiotic is introduced. De-escalation principle is applied, in order to administer the drug effective on our germs but with a narrow spectrum and if possible to avoid the reserve antibiotics.

Natural protective barriers (skin, respiratory and digestive tract) are usually affected in severe burns, along 
with activation of pro-inflammatory cascade getting to a complex immune system disorder, cumulating both cellular and humoral responses to infection; those immunologic alterations determine, in this context infectious complications that are a rule in severe burn evolution marked usually by the presence of opportunistic germs. The most important strategy is the prevention of infectious complications.

According to the evaluated data from our study, we can observe that mortality and substantial morbidities occur and lead to severe debilitation of major burned patients, imposing a continuous adjustment of evaluation and treatment protocols in an adequate infrastructure with sustainable resources.

\section{CONCLUSIONS}

A clear understanding of the physiopathology of burn injuries and their complications is essential for providing an adequate treatment to reduce morbidity and mortality. Mortality still represents the primary outcome measure for burn care, therefore scoring systems aim to use the most predictive patient and injury-related factors to yield an expected mortality for a given patient. ABSI score is a significant predictor of mortality, validated also in our study group. Presence of a series of a negative prognostic factors: patient related

\section{References}

1. Herndon D, Total Burn Care Fourth Edition, Saunders Elsevier 2012.

2. American Burn Association, available on http://ameriburn.org.

3. Colohan SM. Predicting prognosis in thermal burns with associated inhalational injury: a systematic review of prognostic factors in adult burn victims. J Burn Care Res. 2010;31(4):529-39.

4. Knowlin L, Stanford L, Moore D, Cairns B, Charles A. The Measured Effect Magnitude of Co-Morbidities on Burn injury Mortality. Burns : journal of the International Society for Burn Injuries. 2016;42(7):1433-1438

5. Santaniello JM, Luchette FA, Esposito TJ, Gunawan H, Reed RL, Davis KA, Gamelli RL. Ten year experience of burn, trauma, and combined burn/trauma injuries comparing outcomes. J Trauma. 2004;57(4):696-700; discussion 700-1.

6. Hussain A, Dunn KW. Predicting length of stay in thermal burns: a systematic review of prognostic factors. Burns. 2013;39(7): 1331-40.

7. Raff T, Germann G, Barthold U. Factors influencing the early prediction of outcome from burns. Acta Chir Plast. 1996;38(4):1227.

8. Germann G, Barthold U, Lefering R, Raff T, Hartmann B. The impact of risk factors and pre-existing conditions on the mortality of burn patients and the precision of predictive admission-scoring systems. Burns. 1997;23(3):195-203.

9. Blakeney PE, Rosenberg L, Rosenberg M, Faber AW. Psychosocial care of persons with severe burns. Burns. 2008;34(4):43340. (rural provenience, elderly patient), injury-related (extensive and deep burns, mechanism of injury including explosions, electrocutions and chemical burns, presence of inhalation injury, necessity of prolonged intubation and mechanical ventilation) and also infrastructure determinants (insufficient established adequate burn centers and delayed transfers to those center after the injury occurrence) has to be taken into account as they determine higher morbidity and mortality rates in severe burned patients. Early excision of the devitalized tissue and subsequent grafting reduce the local and systemic effects of the mediators released from burned tissue avoiding the progressive inflammatory chain. Prompt recognition and treatment of burns complications, especially severe infections represent an important prevention strategy, improving survival after these severe injuries.

\section{Compliance with ethics requirements:}

The authors declare no conflict of interest regarding this article.

The authors declare that all the procedures and experiments of this study respect the ethical standards in the Helsinki Declaration of 1975, as revised in 2008(5), as well as the national law. Informed consent was obtained from all the patients included in the study.

10. Tobiasen J, Hiebert JM, Edlich RF. The abbreviated burn severity index. Ann Emerg Med. 1982;11(5):260-2.

11. Bittner EA, Shank E, Woodson L, Martyn JAJ. Acute and Perioperative Care of the Burn-Injured Patient. Anesthesiology. 2015 122(2):448-464.

12. Snell JA, Loh N-HW, Mahambrey T, Shokrollahi K. Clinical review: The critical care management of the burn patient. Critical Care. 2013;17(5):241. doi:10.1186/cc12706.

13. Vidal-Trecan G, Tcherny-Lessenot S, Grossin C, Devaux S, Pages $M$, Laguerre J, Wassermann D. Differences between burns in rural and in urban areas: implications for prevention. Burns. 2000;26(4):351-8.

14. Tarim MA. Living in rural areas is a major risk factor for severe burn injury in Turkey. Eastern J Med. 2013; 18(1): 8-12.

15. Mian MA, Haque A, Mullins RF, Fiebiger B, Hassan Z. UrbanRural Dichotomy of Burn Patients in Georgia and South Carolina: A Geographic Information System Study. J Burn Care Res. 2015;36(5):e267-73.

16. Li H, Yao Z, Tan J, et al. Epidemiology and outcome analysis of 6325 burn patients: a five-year retrospective study in a major burn center in Southwest China. Scientific Reports. 2017;7 46066. doi:10.1038/srep46066.

17. Bessey PQ, Arons RR, Dimaggio CJ, Yurt RW. The vulnerabilities of age: burns in children and older adults. Surgery. 2006 140(4):705-15; discussion 715-7. 
18. Lionelli GT, Pickus EJ, Beckum OK, Decoursey RL, Korentager RA. A three decade analysis of factors affecting burn mortality in the elderly. Burns. 2005;31(8):958-63.

19. Lundgren RS, Kramer CB, Rivara FP, et al. Influence of Comorbidities and Age on Outcome Following Burn Injury in Older Adults. Journal of burn care \& research : official publication of the American Burn Association. 2009;30(2):307-314.

20. Jeschke MG, Pinto R, Kraft R, et al. Morbidity and survival probability in burn patients in modern burn care. Critical care medicine. 2015;43(4):808-815

21. Rowan MP, Cancio LC, Elster EA, et al. Burn wound healing and treatment: review and advancements. Critical Care. 2015;19: 243. doi:10.1186/s13054-015-0961-2.

22. Ong YS, Samuel M, Song C. Meta-analysis of early excision of burns. Burns. 2006; 32(2):145-50.

23. Haddad AG, Giatsidis G, Orgill DP, Halvorson EG. Skin Substitutes and Bioscaffolds: Temporary and Permanent Coverage. Clin Plast Surg. 2017; 44(3):627-634.

24. Zaulyanov L, Kirsner RS. A review of a bi-layered living cell treatment (Apligraf ${ }^{\circledR}$ ) in the treatment of venous leg ulcers and diabetic foot ulcers. Clinical Interventions in Aging. 2007; 2(1):9398.

25. Dries DJ, Endorf FW. Inhalation injury: epidemiology, pathology, treatment strategies. Scandinavian Journal of Trauma, Resuscitation and Emergency Medicine. 2013;21:31. doi:10.1186/ 1757-7241-21-31.

26. Shirani KZ, Pruitt Jr BA, Mason Jr AD. The influence of inhalation injury and pneumonia on burn mortality. Ann Surg. 1987; 205:82-7.

27. Endorf FW, Gamelli RL. Inhalation injury, pulmonary perturbations, and fluid resuscitation. J Burn Care Res. 2007; 28:80-3.

28. Swanson JW, Otto AM, Gibran NS, et al. Trajectories to death in patients with burn injury. J Trauma Acute Care Surg 2013; $74: 282-8$

29. Wise B, Levine Z. Inhalation injury. Canadian Family Physician. 2015;61(1):47-49
30. Mlcak RP, Inhalation injury from heat, smoke, or chemical irritants, from UpToDate 2018, available on www.uptodate.com.

31. Walker PF, Buehner MF, Wood LA, et al. Diagnosis and management of inhalation injury: an updated review. Critical Care. 2015; 19:351. doi:10.1186/s13054-015-1077-4.

32. Hassan Z, Wong JK, Bush J, Bayat A, Dunn KW. Assessing the severity of inhalation injuries in adults. Burns. 2010; 36:212-6.

33. Ryan CM, Fagan SP, Goverman J, Sheridan RL. Grading inhalation injury by admission bronchoscopy. Crit Care Med. 2012 40:1345-6.

34. Mlcak RP, Suman OE, Herndon DN. Respiratory management of inhalation injury. Burns 2007, 33:2-13

35. Endorf FW, Dries DJ. Noninvasive ventilation in the burned patient. J Burn Care Res 2010, 31:217-228.

36. Brochard L. Noninvasive ventilation for acute respiratory failure JAMA 2002, 288:932-935.

37. Gravvanis Al, Tsoutsos DA, Iconomou TG, Papadopoulos SG Percutaneous versus conventional tracheostomy in burned patients with inhalation injury. World J Surg 2005, 29:1571-1575.

38. Pierson DJ. Tracheostomy and weaning. Respir Care. 2005; 50(4):526-33

39. Durbin CG Jr. Tracheostomy: why, when, and how? Respir Care 2010; 55(8):1056-68

40. Kagan RJ, Gamelli R, Saffle JR. DRG 504: the effect of 96 hours of mechanical ventilation on resource utilization. J Burn Care Res. 2007; 28(5):664-8.

41. Forster NA, Zingg M, Haile SR, Künzi W, Giovanoli P, Guggenheim M. 30 years later-does the ABSI need revision? Burns. 2011 37(6):958-63.

42. Bakhtyar N, Sivayoganathan $T$, Jeschke MG. Therapeutic Approaches to Combatting Hypermetabolism in Severe Burn Injuries. J Intensive \& Crit Care. 2015; 1(6):1-12.

43. Nielson CB, Duethman NC, Howard JM, Moncure M, Wood JG Burns: Pathophysiology of Systemic Complications and Current Management. Journal of Burn Care \& Research. 2017 38(1):e469-e481. 